\title{
Effect of Harvest Time, Delay in Destemming and Desapping Treatment on the Sap Volume and Visual Quality of 'Carabao' Mango Fruit
}

\section{Leizel SECRETARIA ${ }^{1}$, Emma Ruth BAYOGAN ${ }^{1, *}$, Christine Diana LUBATON ${ }^{1}$, Ana Maria Carmela MAJOMOT ${ }^{1}$, Jennifer EKMAN ${ }^{2}$ and Adam GOLDWATER ${ }^{2}$}

\author{
${ }^{I}$ University of the Philippines Mindanao, Davao City, Philippines \\ ${ }^{2}$ Applied Horticultural Research, Eveleigh NSW 2015, Australia
}

('Corresponding author's e-mail: evbayogan@up.edu.ph)

Received: 26 October 2019, Revised: 22 June 2020, Accepted: 24 July 2020

\begin{abstract}
The sap or latex injury in mango reduces fruit quality as it causes skin blemish during harvesting and postharvest handling. Sap volume and visual quality of 'Carabao' mango as affected by different harvest times during the day (every hour from 7:00 AM to 5:00 PM), delay in cutting (hourly up to $6 \mathrm{~h}$ ) of the pedicel at either the pedicel base or at the abscission zone and different desapping agents applied 1 or $7 \mathrm{~h}$ from harvest were assessed. Sap injury was assessed by allowing the sap to flow on the fruit after recutting the pedicel at the abscission zone. Sap volume was measured during harvesting while sap injury, days to table ripe stage, visual quality, weight loss, degree of anthracnose and stem end rot were assessed during fruit storage. The experiments were laid out using the completely randomized design. Sap volume ranged from 0.06 to $0.25 \mathrm{~mL}_{\text {fruit }^{-1}}$. The lowest sap volume was recorded in fruit harvested in the afternoon between 1:00 and 5:00 PM, while the highest volume was noted at 7:00 and 10:00 AM. The relative humidity of the air was highest at 7:00 AM. Better quality at table ripe stage was noted in mango fruit harvested at 1:00 - 2:00 and 4:00 - 5:00 PM. Sap injury at different harvest times did not vary. The delay in the destemming up to $6 \mathrm{~h}$ and the location of cut or pedicel length did not affect sap volume and fruit quality. However, the cutting of the pedicel at the abscission zone rather than at the pedicel base tended to result in better quality, which helped delay fruit ripening. All desapping treatments, such as 1.0 $\%$ alum, $1.0 \%$ detergent, $0.5 \%$ lime $\left[\mathrm{Ca}(\mathrm{OH})_{2}\right]$, and water, could control sap injury. Untreated fruit showed longer shelf life due to a lower degree of anthracnose. Stem-end rot did vary among desapping agents. Among the desapping treatments, water is found to reduce sap damage better. Harvesting later in the day, cutting at the abscission zone, and washing mangoes with water can reduce sap or latex damage in 'Carabao' mango.
\end{abstract}

Keywords: Abscission zone, Desapping, Sap injury, Visual quality, Mango fruit, Carabao

\section{Introduction}

The mango, Mangifera indica, is an important rather than essential fruit in the Philippines. The Philippine 'Carabao' mango is among the well known cultivars grown in Southeast Asia as well as in the Southern Pacific region [1]. This mango cultivar, also known as 'Manila Super Mango' or 'Luzon Mango' in the international market, is the country's best variety because of its distinct sweet taste. However, the mango industry faces various problems in maintaining quality along the handling chain. High postharvest losses in mango occur due to the lengthy processes in the handling chain such as harvesting, transportation, ripening, and storage. Such losses are compounded by a lack of postharvest facilities and poor handling practices. 
http://wjst.wu.ac.th

One of the serious problems in mango production which affects mango quality is sap or latex injury. It lowers fruit quality and economic value as it causes serious skin damage on 'Carabao' mangoes resulting in rejections upon delivery in a fresh fruit packinghouse [2]. Sap injury or sap burn in 'Carabao' mango may occur when the sap spurts on the catching net when harvesting fruit [3]. When the pedicel is cut during harvest, the sap initially spurts out on the fruit surface, and it continuously oozes out of the pressurized fruit ducts [4]. Sap on fruit surface causes sap injury characterized by darkening or browning of the peel [5].

Various interventions to control sap injury in mango have been reported, such as harvesting of fruit at different times of the day [6]; use of desapping tray where the fruit was desapped for $20 \mathrm{~min}$ [7], and use of $0.5 \%$ and $1 \%$ alum, $1 \%$ sodium hydroxide, $1 \%$ calcium hydroxide (lime) as desapping agents [8]. Sap injury in 'Samar Bahisht Chaunsa' mango fruit was minimized when harvested and desapped in the morning (7:00 AM) compared to noon time (12:00 PM) [6]. Lower sap injury was also observed in 'Sindhri' and 'Chaunsa' mango fruit when harvested at 8:00 AM compared to harvesting at 3:00 PM [7]. The desapping of fruit on the tray for $20 \mathrm{~min}$ reduced the sap injury compared to desapping for $10 \mathrm{~min}$ and the traditional method (without desapping) [7]. Washing of fruit with sodium hydroxide $(1 \%)$ showed lower sap injury followed by alum (1\%) [8]. It was reported that lime solution $\left[1 \% \mathrm{Ca}(\mathrm{OH})_{2}\right]$ also reduced sap injury in mango [6]. When destemming was delayed, the sap quantity tended to decrease but did not vary if the fruit were destemmed immediately after harvest [7].

Reports related to sap management in 'Carabao' mango are limited. These reports include the use of chemical and physical treatments, harvesting late in the morning to afternoon (9:00 AM to 3:00 PM), and washing of mango with water in the packinghouse to remove sap stain [9-11]. The use of ultrasonic washing with aluminum potassium sulfate (alum) controlled sap injury in 'Carabao' mango [9]. Two effective chemical and physical methods in removing sap in 'Carabao' mango were $1 \%$ alum and hot water treatment (HWT at 52 to $55^{\circ} \mathrm{C}$ for $10 \mathrm{~min}$ ), respectively [11]. In this study, the sap quantity, sap injury, and visual quality of 'Carabao' mango in relation to the time of harvest, location of pedicel cut, time of destemming and desapping using different chemicals at different times after harvest were evaluated to determine some practical methods to reduce quality losses in mango due to sap injury.

\section{Materials and methods}

Sap volume, injury and visual quality in relation to time of harvesting within the day

The sap volume estimation on newly-harvested 'Carabao' mango was conducted at the Cuevas Mango Farm in Samal Island, Davao del Norte on 14 April 2016. Uniform, medium-sized and commercially mature 'Carabao' mango fruit (105 days after flower induction) were randomly harvested from two trees. Fruit samples from the field were brought to the Postharvest Biology Laboratory at the University of the Philippines Mindanao, Davao City for further quality evaluation. All fruit samples were placed in a plastic crate with cushion material, handled carefully and transported to the laboratory using an air-conditioned van.

For each designated hourly harvest time between 7:00 AM to 5:00 PM, a set of 6 medium fruit samples of uniform quality were randomly harvested from different parts of the canopy. A total of 66 fruit were used to measure the sap quantity. Each fruit was harvested by cutting the pedicel to at least $10 \mathrm{~cm}$ long and subsequently re-cutting it at the abscission zone. The sap was collected in a glass container until no sap flow was observed for about $3 \mathrm{~min}$. Sap volume was measured using a $1 \mathrm{~mL}$ syringe. Fruit surface temperature was measured using an Extech infrared thermometer, while field air temperature and relative humidity were measured using a HOBO UX100-003 temperature/relative humidity data logger.

In a $2^{\text {nd }}$ experiment, another set of 6 mango samples were subjected to sap flow every hour between 7:00 AM to 5:00 PM. A total of 66 fruit were used to assess the effect of sap on the fruit's surface at different harvest times. The individual fruit was positioned in an upright position with the shoulder on top similar to how the fruit developed in the tree. Fruit was initially harvested with pedicels at least $10 \mathrm{~cm}$ long. The sap was allowed to flow on the fruit surface after re-cutting the pedicel at the abscission zone. The extent of sap injury was observed in the laboratory. Visual quality at four days after harvest and at table ripe stage (TRS), days to TRS and degree of sap injury at four days after harvest were recorded in 
http://wjst.wu.ac.th

the laboratory. Visual quality was assessed using the scale: 1) excellent, field fresh; 2) very good, minor defects; 3) good, moderate defects; 4) fair, serious defects, limit of saleability; 5) non-edible under usual conditions [12]. The sap injury was evaluated using a modified scale on percentage of surface area with injury: 1) no sap injury, 2) $1-15 \%$ sap injury in surface area, 3) $16-45 \%$, 4) $5-60 \%$ and 5) $>60 \%$ $[5]$.

Sap volume and visual quality as affected by a delay in destemming and pedicel location at destemming

To determine the effect of delay in cutting the pedicel, medium-sized mango fruit of uniform good visual quality were harvested from two trees at 7:00 AM. The fruits were carefully placed in a plastic tray until they were ready to be cut either at the pedicel base or at the abscission zone (Figure 1). The treatments involved the delayed time of destemming and location of cut in the pedicel of fruit. Six fruit samples were simultaneously cut either at the base of the pedicel (near the shoulder of the fruit) or the abscission zone (about half a centimeter from the base). Delayed cutting of the pedicel was done every hour between 7:00 AM to 1:00 PM (or a delay of 0 to $6 \mathrm{~h}$ ). The sap was collected in glass containers, and its volume was measured using a $1 \mathrm{~mL}$ syringe. Visual quality and days to TRS were observed further in the laboratory.

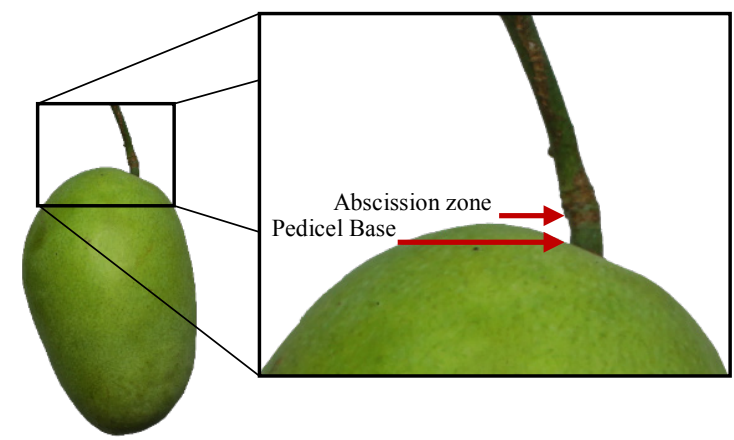

Figure 1 'Carabao' mango fruit showing part of the pedicel, the abscission zone and the base of the pedicel.

\section{Sap injury and visual quality of mango as affected by desapping treatment}

To evaluate the effect of desapping treatment, 60 medium-sized mango fruit of uniform, good visual quality were harvested at 8:00 AM. The sap was allowed to flow onto the fruit after harvest and was subjected to desapping treatment. Fruit were divided into four sets with 15 fruit dipped in a $0.5 \%$ lime solution $\left[\mathrm{Ca}(\mathrm{OH})_{2}\right], 1 \%$ alum, or water for three minutes after seven hours from harvest. One set of 15 fruit served as the control or untreated treatment.

Another trial in desapping was done in a farm in Los Amigos district, Davao City, in June 2016. A total of 120 green mature mango fruits were harvested at 8:00 AM from 2 trees, wherein 60 fruit were used for each time of desapping treatment, after one or seven hours from harvest. For each time of desapping treatment, samples were divided into five lots with 12 samples per treatment (control or without treatment, alum, detergent, lime solution, and water). Fruit was dipped in either $1 \%$ alum (w/v), $1 \%$ detergent $(\mathrm{w} / \mathrm{v}), 0.5 \%(\mathrm{w} / \mathrm{v})$ lime solution $\left[\mathrm{Ca}(\mathrm{OH})_{2}\right]$, or water for $3 \mathrm{~min}$ after 1 or $7 \mathrm{~h}$ from harvest.

Visual quality, sap injury, disease incidence of anthracnose and stem-end rot (SER), and end of shelf life were evaluated in the laboratory. Fruit reached the end of shelf life when it exhibited a visual quality of 4 (fair, serious defects, the limit of saleability), degree of anthracnose, or SER at a rating scale of 3. The degree of anthracnose and stem-end rot diseases were measured using a slightly modified anthracnose and stem-end rot rating [13]. Anthracnose was assessed using the following scale: 1) no 
http://wjst.wu.ac.th

visible spots, 2) 1 depressed spot, dark in color with $1-5 \mathrm{~mm}$ in diameter on the epidermis of the fruit, 3) 2 - 3 depressed spots, dark in color with 1 - $5 \mathrm{~mm}$ in diameter, 4) 2 - 3 depressed spots, dark in color with more than $5 \mathrm{~mm}$ in diameter, 5) more than three depressed spots, dark in color with more than $5 \mathrm{~mm}$ in diameter, 6) depressed spots merged. SER was evaluated using the following scale: 1) no discoloration of the stem end, 2) discoloration limited at the stem end, 3) $10 \%$ discoloration of the fruit surface area initiated by stem-end rot, 4) $11-30 \%$ discoloration of the fruit surface area initiated by stem-end rot, 5) $31-50 \%$ discoloration of the surface area initiated by stem-end rot, 6) more than $51 \%$ discoloration of the surface area initiated by stem-end rot.

Data analysis

Data were analyzed using Analysis of variance (ANOVA). All the experiments followed a Completely Randomized Design (CRD). Treatment means were compared using Least Significant Difference (LSD) test at $\mathrm{p} \leq 0.05$.

\section{Results and discussion}

\section{Sap volume, injury and visual quality in relation to time of harvesting}

Sap quantity or volume recorded in 'Carabao' mango ranged from 0.06 to $0.25 \mathrm{~mL}^{\text {fruit }}{ }^{-1}$. The lowest sap volume was recorded in fruit harvested at 1:00 to 5:00 PM, while the highest volume was noted at 7:00 to 10:00 AM (Figure 2). Relative humidity (RH) showed a moderate positive correlation with sap volume $\left(\mathrm{r}=0.469^{* *}\right)$. Fruit harvested during the lowest $\mathrm{RH}$ of the day tended to produce lower sap volume. This contrasted with fruit harvested at the highest RH of the day, where sap production tended to be higher. This shows that the surrounding condition like RH may influence the production of sap. Notwithstanding, it may be advantageous to harvest the 'Çarabao' mango fruit in the late morning until in the afternoon, from 11:00 AM to 5:00 PM, as sap volume was low. The higher sap volume in the morning might be due to high water content or turgor pressure, which decreased as temperature increased [8]. However, in this study, the temperature did not appear to indicate a trend with sap production. On the other hand, higher humidity may reduce water loss, contributing to significantly higher sap quantity in the morning.

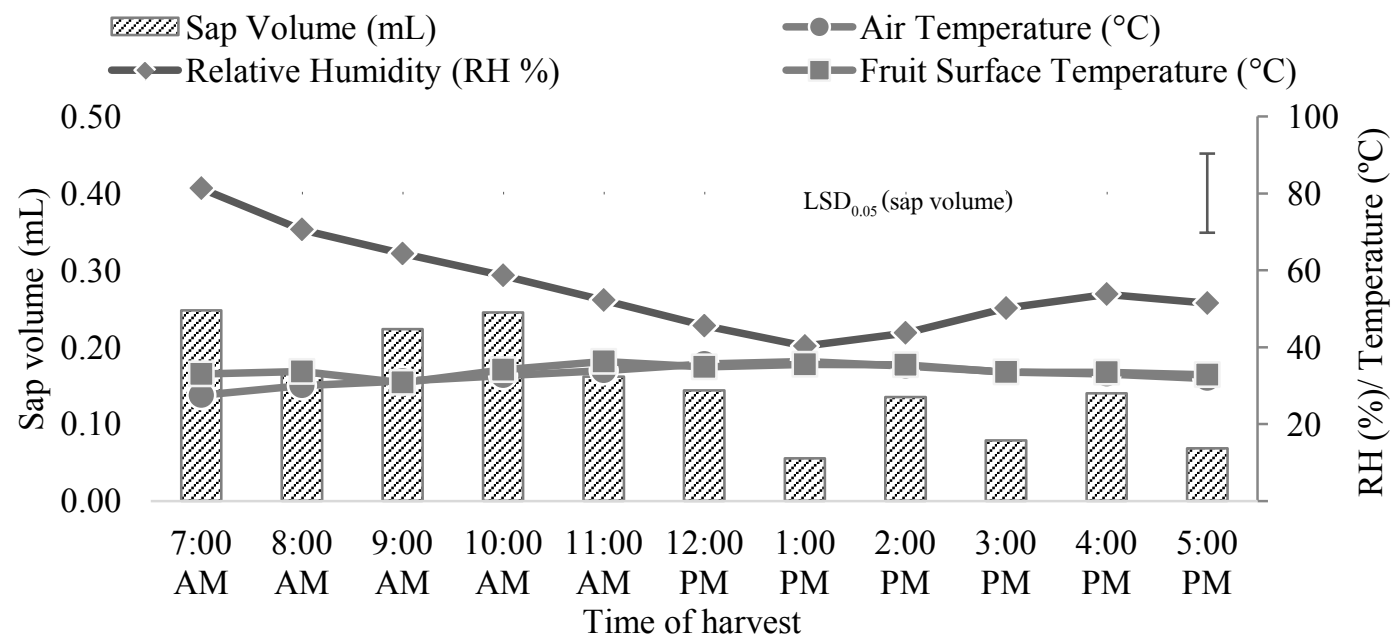

Figure 2 Sap volume, fruit surface temperature and relative humidity (RH) of 'Carabao' mango fruit harvested at various times during the day.

The higher relative humidity may result in lower transpiration, and this was shown in a reduction of water loss by 30 - $50 \%$ in peach fruit with the increase of relative humidity from 40 to $60 \%$ [14]. 
http://wjst.wu.ac.th

Further, a diurnal pattern in the sap flow of water in the pedicel of mature mango fruit has been reported, wherein sap came out from fruit in the daytime and flowed into the fruit during the night [15]. It has been recommended to harvest 'Carabao' mango from 9:00 AM to 3 PM since harvesting too early in the morning would cause a rapid flow of sap from the pedicel end [11]. The high solar radiation and vapor pressure deficit increased the stem water flow in mature fruit, peaking in the morning and gradually decreasing after the peak before midday [15]. In the present study, the increase of sap flow in the early morning was evident in a higher volume of sap collected, which gradually decreased starting at the midday period. Sap flow in the morning was reported to be caused by midday water stress in which leaf transpiration was high, resulting in water shortage in the stem [15].

Though not significant, fruit harvested in the morning, where sap was intentionally allowed to flow on the fruit, tended to show higher sap injury, contributing to lower visual quality. Better quality of fruit at four days after harvesting (DAH) was observed when the fruit was harvested at 1:00 - 2:00 and 4:00 5:00 PM (Table 1). Mango visual quality did not vary at the table ripe stage (TRS). During the day, the time of harvest appeared to influence the visual quality of mango, in this case only at 4 DAH. This was probably because of the higher production of sap during the morning, in which sap injury was one of the contributing factors in lowering the visual quality. However, the lower visual quality of fruit harvested at 3:00 PM may also be due to some other factors like shriveling and decaying as the fruit ripened.

Table 1 Sap injury, visual quality (VQ) and days to table ripe stage (TRS) of 'Carabao' mango harvested at various times of the day.

\begin{tabular}{|c|c|c|c|c|}
\hline Time of harvest & Sap injury at $4 \mathrm{DAH}^{\mathrm{ns}}$ & VQ at 4 DAH* & VQ at TRS $S^{\text {ns }}$ & Days to TRS $^{\mathrm{n}}$ \\
\hline 7:00 AM & 2.67 & $2.83 \mathrm{a}$ & 3.20 & 6.00 \\
\hline 8:00 AM & 3.17 & $2.83 \mathrm{a}$ & 2.75 & 7.00 \\
\hline 9:00 AM & 2.83 & $2.67 \mathrm{a}$ & 2.67 & 6.67 \\
\hline 10:00 AM & 2.67 & $2.50 \mathrm{a}$ & 2.60 & 6.60 \\
\hline 11:00 AM & 3.00 & $2.50 \mathrm{ab}$ & 2.75 & 5.50 \\
\hline 12:00 PM & 2.50 & $2.33 \mathrm{ab}$ & 2.50 & 6.67 \\
\hline 1:00 PM & 2.67 & $1.83 \mathrm{~b}$ & 2.60 & 7.00 \\
\hline 2:00 PM & 2.33 & $1.67 \mathrm{c}$ & 2.40 & 7.20 \\
\hline 3:00 PM & 2.50 & $2.50 \mathrm{a}$ & 3.00 & 7.00 \\
\hline 4:00 PM & 2.17 & $1.83 \mathrm{bc}$ & 2.17 & 7.00 \\
\hline 5:00 PM & 2.00 & $1.83 \mathrm{bc}$ & 2.00 & 7.00 \\
\hline
\end{tabular}

"Means in a column with the same letter/s are not significantly different using LSD test at $5 \%$ level of significance. ${ }^{\text {ns }}$ not significant; days after harvesting (DAH). Visual quality (VQ): 1) excellent, field fresh; 2) very good, minor defects; 3) good, moderate defects; 4) fair, serious defects, limit of saleability; 5) non-edible under usual conditions. Sap injury: 1) no sap injury, 2) $1-15 \%$ sap injury in surface area, 3) $16-45 \%$, 4) $46-60 \%$ and 5) $>60 \%$. 
http://wjst.wu.ac.th

It has been reported that there was a reduced amount of sap in mango packed in a film with lower $\mathrm{RH}$ while there was a higher accumulation of sap in a film with higher $\mathrm{RH}$ [16]. In previous studies, mango fruit harvested in the morning (at 7:00 and 9:30 AM) was reported to show lower sap injury than in the afternoon (at 12:00 and 2:00 PM) [7,8] despite the higher sap volume. In contrast, fruit harvested in the morning tended to show higher sap injury resulting in lower quality of fruit in the present study. An increase in fruit surface transpiration with an increase of temperature leads to reduced water concentration and ultimately more concentrated terpinolene oil content of saps [7]. This results in increased viscosity of sap because of lower water and higher oil content [7,8]. The terpinolene content of oil in sap primarily causes sap injury as it enters the skin through lenticels [17]. Thus, higher sap injury in the afternoon than in the morning was reported in previous studies, which contrasts with the present findings. Relatively lower sap damage of mango harvested in the afternoon may be due to different sap components in 'Carabao' mango as sap injury and quantity vary among cultivars [2,7]. There might be a higher concentration of the sap component that causes injury when harvesting 'Carabao' mango in the morning, such as the oil content in the aqueous phase and spurt sap. The differences in sap injury in mango were probably due to varietal variation in the volume and concentration of sap's individual components [2].

Sap injury was reported as dependent on the upper non-aqueous and lower aqueous phase of sap [18] as well as the spurt and ooze sap [8]. Spurt sap is exuded from the fruit during the $1 \mathrm{st} 10 \mathrm{~s}$ after cutting the pedicel, while the ooze sap is the remaining sap that is released more slowly [4]. Spurt sap caused a higher amount of mango injury at $100 \%$ compared to $2.5 \%$ damage in oozing sap which only caused non-caustic shiny and glassy streaks in mango skin [19]. The higher amount of non-aqueous phase in a spurt, which is 20 times more than in ooze sap contributes to more damaging burn injury in fruit [4]. The aqueous phase was milky and viscous, containing mostly proteins and polysaccharides, while the non-aqueous phase was yellowish and consisted mainly of oil composed of terpenoids that cause damage [4,18]. The 2 phases of sap, its components, and amounts were not determined in the present study. Measuring the sap components and its amount in 'Carabao' mango may provide further insights as sap injury varies among cultivars.

Table 2 Sap volume, visual quality (VQ) and days to table ripe stage (TRS) of fruit as influenced by location of cut and delay in cutting of pedicel.

\begin{tabular}{|c|c|c|c|c|c|c|c|c|c|}
\hline \multirow{2}{*}{ Time } & \multirow{2}{*}{$\begin{array}{l}\text { Number of } \\
\text { hours delay }\end{array}$} & \multicolumn{2}{|c|}{ Sap volume $(\mathrm{mL})^{\mathrm{ns}}$} & \multicolumn{2}{|c|}{ VQ at $4 \mathrm{DAH}^{\mathrm{ns}}$} & \multicolumn{2}{|c|}{ VQ at $T_{R S}{ }^{n s}$} & \multicolumn{2}{|c|}{ Days to $\mathrm{TRS}^{\mathrm{ns}}$} \\
\hline & & Base & $\overline{A Z}$ & Base & $\overline{\mathbf{A Z}}$ & Base & $\mathbf{A Z}$ & Base & $\overline{\mathbf{A Z}}$ \\
\hline 7:00 AM & 0 & 0.13 & 0.16 & 1.67 & 1.67 & 2.83 & 2.17 & 5.33 & 6.67 \\
\hline 8:00 AM & 1 & 0.15 & 0.13 & 1.83 & 1.33 & 2.33 & 2.20 & 5.33 & 6.33 \\
\hline 9:00 AM & 2 & 0.23 & 0.15 & 1.67 & 1.33 & 2.00 & 2.50 & 6.00 & 6.33 \\
\hline 10:00 AM & 3 & 0.15 & 0.13 & 1.67 & 1.50 & 2.33 & 2.25 & 5.33 & 6.50 \\
\hline 11:00 AM & 4 & 0.15 & 0.11 & 2.00 & 1.00 & 3.20 & 2.00 & 5.60 & 6.50 \\
\hline 12:00 PM & 5 & 0.09 & 0.09 & 1.50 & 1.33 & 2.33 & 2.40 & 5.33 & 6.20 \\
\hline 1:00 PM & 6 & 0.10 & 0.09 & 2.00 & 1.33 & 2.40 & 2.00 & 6.00 & 8.33 \\
\hline \multicolumn{10}{|c|}{ Correlation coefficient } \\
\hline \multicolumn{4}{|c|}{ Pedicel location cut and visual quality } & & \multicolumn{3}{|c|}{$-0.373 * *$} & & \\
\hline \multicolumn{4}{|c|}{ Pedicel location cut and days to TRS } & & \multicolumn{3}{|c|}{$-0.438^{* *}$} & & \\
\hline
\end{tabular}

${ }^{\mathrm{ns}}$ Not significant; days after harvesting (DAH); abscission zone (AZ). Visual quality (VQ): 1) excellent, field fresh; 2) very good, minor defects; 3) good, moderate defects; 4) fair, serious defects, limit of saleability; 5) non-edible under usual conditions. 


\author{
Sap volume and visual quality as affected by a delay in destemming and pedicel location at de- \\ stemming \\ Sap volume was not affected by a delay in destemming either in the zone or base of the pedicel
} (Table 2). Fruit visual quality, sap injury, and days to TRS were similar (Table 2). Thus, sap production is not affected by the delayed cutting of the pedicel and location of the cut. Sap volume recorded during 0 to $6 \mathrm{~h}$ of delay in destemming in 'Carabao' mango ranged from 0.09 to $0.23 \mathrm{~mL}_{\text {fruit }}{ }^{-1}$ when the fruit was cut in pedicel base while 0.09 to $0.16 \mathrm{~mL}^{\text {fruit }}{ }^{-1}$ in abscission zone. The highest volume of sap was recorded when the pedicel was cut at the base $\left(0.23 \mathrm{~mL}_{\text {fruit }}{ }^{-1}\right)$.

Though the quality of the fruit was similar in the two pedicel treatments, cutting of pedicel at the abscission zone rather than at the pedicel base tended to result in a slightly better visual fruit quality. This is supported by a positive correlation of location cut with visual quality $\left(\mathrm{r}=0.373^{* *}\right)$. Further, cutting of pedicel at the abscission zone seemed to delay ripening as shown by the negative relationship with the days to TRS ( $\mathrm{r}=-0.438 * *)$.

In the field, the sap is readily exuded from the fruit immediately after cutting the pedicel either in the abscission or base zone. This very short time, about $5 \mathrm{~s}$, of which fruit is in contact with the sap, can allow the sap to sufficiently penetrate the fruit skin leading to permanent sap injury or burn [20]. Delaying the cutting of the pedicel after harvest might control the amount of sap exuded from fruit and its contact with the fruit surface. However, it has been reported that there is little effect of delay in destemming on sap quantity, as observed in this study [17]. The decreasing quantity of sap exuded with delays in destemming might be due to high water pressure in the fruit that decreases over time [17]. Short pedicel length at the time of harvest causes sap to flow on the fruit's skin, which was also observed in this study [18]. Mango with a longer pedicel (approximately $1 \mathrm{~cm}$ ) had a better quality of fruit due to the reduction of anthracnose and delay in onset of stem-end rot [21]. The sap component that protects plants from pathogens is the alk(en)ylresorcinols which were found to be higher in the peel of anthracnoseresistant varieties [17]. In avocado, attached peduncle and pedicel delayed ripening [18] which was also observed in the present study. It was suggested that the peduncle might act as a source of a ripening inhibitor to the fruit or a sink for the ripening hormone produced in the fruit [18].

Table 3 Sap injury, number of days to table ripe stage (TRS), visual quality (VQ) at TRS, and weight loss of 'Carabao' mangoes exposed to various desapping treatments $7 \mathrm{~h}$ from harvest.

\begin{tabular}{|c|c|c|c|c|}
\hline Treatment & Sap injury at 4 DAT* & Days to TRS* & VQ at $T_{R S}{ }^{n s}$ & Weight loss at TRS, \%* \\
\hline Control & $3.3^{\mathrm{a}}$ & $7.2^{\mathrm{a}}$ & 2.6 & $20.27^{\mathrm{a}}$ \\
\hline Lime, $0.5 \%$ & $2.1^{\mathrm{b}}$ & $6.0^{\mathrm{b}}$ & 2.5 & $14.04^{\mathrm{b}}$ \\
\hline Alum, $1.0 \%$ & $1.9^{\mathrm{bc}}$ & $6.3^{\mathrm{ab}}$ & 2.4 & $17.76^{\mathrm{ab}}$ \\
\hline Water & $1.5^{\mathrm{c}}$ & $7.4^{\mathrm{a}}$ & 2.4 & $21.27^{\mathrm{a}}$ \\
\hline
\end{tabular}

* Means in a column with the same letter/s are not significantly different using LSD test at $5 \%$ level of significance.

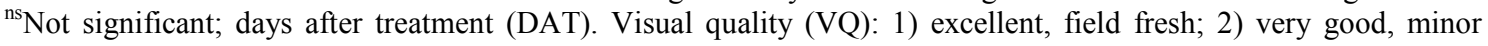
defects; 3) good, moderate defects; 4) fair, serious defects, limit of saleability; 5) non-edible under usual conditions. Sap injury: 1) no sap injury, 2) $1-15 \%$ sap injury in surface area, 3) $16-45 \%$, 4) 5 - $60 \%$ and 5) $>60 \%$.

\section{Sap injury and visual of mango as affected by desapping treatment}

All desapping treatments reduced sap injury (Table 3) at four days after treatment (DAT) but not the visual quality at TRS. Lower sap injury was observed in fruit washed with water, but this did not vary with fruit washed with $1 \%$ alum. Longer days to TRS and higher weight loss were recorded in control and fruit washed with water. Weight loss was lower in fruit treated with lime $(0.5 \%)$, but this did not vary with $1 \%$ alum. The visual quality of 1 and $7 \mathrm{~h}$ desapped fruit from harvest mostly decreased through time in all treatments, except for fruit washed with water at $7 \mathrm{~h}$ after harvest (Table 4). Lower 
http://wjst.wu.ac.th

anthracnose but shorter shelf life was observed in fruit washed with lime after one $\mathrm{h}$ from harvest. All desapping agents were able to reduce sap injury if desapping was done 1 or $7 \mathrm{~h}$ from harvest. Better visual quality was observed in fruit washed with water.

For the $7 \mathrm{~h}$ desapped fruit, sap injury increased in fruit washed with alum (1\%) and detergent $(1 \%)$ at TRS. Lime-treated mangoes had the lowest visual quality as they imparted pronounced browning in sap burned areas in the mango peel after the treatment. Sap injury was reduced in water which was comparable with other washing agents resulting in better quality and longer shelf life. It is recommended to wash the sap injured mangoes at an earlier time to attain better visual quality. Still, water was a better washing agent for sap injury than alum, lime, and detergent.

Table 4 Quality of 'Carabao' mango fruit after desapping treatments at 1 or $7 \mathrm{~h}$ after harvest.

\begin{tabular}{|c|c|c|c|c|c|c|c|}
\hline \multirow{2}{*}{ Treatment } & \multicolumn{3}{|c|}{ Visual quality* } & \multirow{2}{*}{$\frac{\text { Sap injury }}{\text { at TRS* }}$} & \multirow{2}{*}{$\begin{array}{l}\text { Anthracnose } \\
\text { at TRS* }\end{array}$} & \multirow{2}{*}{$\begin{array}{c}\text { SER at } \\
\text { TRS }^{\text {ns }}\end{array}$} & \multirow{2}{*}{$\begin{array}{l}\text { Shelf life } \\
\text { (days)* }\end{array}$} \\
\hline & Initial & 1 DAT & at TRS & & & & \\
\hline \multicolumn{8}{|c|}{ Desapping at $1 \mathrm{~h}$ after harvest } \\
\hline Control & $2.25^{\mathrm{ab}}$ & $3.67^{\mathrm{a}}$ & $3.42^{\mathrm{a}}$ & $3.58^{\mathrm{a}}$ & $1.92^{\mathrm{bc}}$ & 2.00 & $9.50^{\mathrm{a}}$ \\
\hline Alum, $1.0 \%$ & $2.42^{\mathrm{a}}$ & $2.25^{\mathrm{b}}$ & $3.17^{\mathrm{ab}}$ & $2.33^{\mathrm{b}}$ & $2.00^{\mathrm{abc}}$ & 1.42 & $9.08^{\mathrm{ab}}$ \\
\hline Detergent, $1.0 \%$ & $2.08^{\mathrm{b}}$ & $2.17^{\mathrm{b}}$ & $3.41^{\mathrm{a}}$ & $2.13^{\mathrm{b}}$ & $2.58^{\mathrm{a}}$ & 2.17 & $9.92^{\mathrm{a}}$ \\
\hline Lime, $0.5 \%$ & $2.00^{\mathrm{b}}$ & $2.00^{\mathrm{b}}$ & $3.67^{\mathrm{a}}$ & $2.33^{\mathrm{b}}$ & $1.42^{\mathrm{c}}$ & 2.75 & $8.08^{\mathrm{b}}$ \\
\hline Water & $2.00^{\mathrm{b}}$ & $1.92^{\mathrm{b}}$ & $2.88^{\mathrm{b}}$ & $2.42^{\mathrm{b}}$ & $2.08^{\mathrm{ab}}$ & 1.75 & $9.17^{\mathrm{a}}$ \\
\hline \multicolumn{8}{|c|}{ Desapping at $7 \mathrm{~h}$ after harvest } \\
\hline Control & $2.33^{\mathrm{a}}$ & 2.58 & $3.17^{\mathrm{bc}}$ & $2.83^{\mathrm{a}}$ & $1.83^{\mathrm{bc}}$ & 1.42 & $9.67^{\mathrm{ab}}$ \\
\hline Alum, $1.0 \%$ & $2.25^{\mathrm{a}}$ & 3.00 & $3.58^{\mathrm{ab}}$ & $2.25^{\mathrm{b}}$ & $2.33^{\mathrm{ab}}$ & 1.83 & $8.17^{\mathrm{c}}$ \\
\hline Detergent, $1.0 \%$ & $2.17^{\mathrm{a}}$ & 2.58 & $3.17^{\mathrm{bc}}$ & $2.08^{\mathrm{bc}}$ & $2.75^{\mathrm{a}}$ & 1.17 & $8.50^{\mathrm{bc}}$ \\
\hline Lime, $0.5 \%$ & $2.25^{\mathrm{a}}$ & 2.58 & $4.00^{\mathrm{a}}$ & $2.00^{\mathrm{bc}}$ & $1.83^{\mathrm{bc}}$ & 2.42 & $8.92^{\mathrm{abc}}$ \\
\hline Water & $2.00^{\mathrm{a}}$ & 2.83 & $2.79^{\mathrm{c}}$ & $1.83^{\mathrm{c}}$ & $1.58^{\mathrm{c}}$ & 1.50 & $9.92^{\mathrm{a}}$ \\
\hline
\end{tabular}

*Per desapping time, in a column, means with the same letter are not significantly different using LSD test at $5 \%$ level of significance. ${ }^{\text {ns }}$ Not significant; days after treatment (DAT); table ripe stage (TRS). Visual quality (VQ): 1) excellent, field fresh; 2) very good, minor defects; 3) good, moderate defects; 4) fair, serious defects, limit of saleability; 5) non-edible under usual conditions. Sap injury: 1) no sap injury, 2) 1 - $15 \%$ sap injury in surface area, 3) $16-45 \%$, 4) $5-60 \%$ and 5) $>60 \%$.

The management of sap injury in mango is primarily focused on neutralizing the acidic nature of sap through basic solution [7]. A series of experiments on desapping was conducted in which hydrated lime was superior to other chemicals in reducing sap injury [21]. Calcium hydroxide (1\%) or lime has a strong base with a $\mathrm{pH}=12.4$ and is widely used as an inexpensive alkali to neutralize the effect of strongly acidic sap with a $\mathrm{pH}=4.3$ [23]. However, lime was not as effective as alum $(0.5$ and $1 \%)$ in reducing sap injury in 'Samar Bahisht Chaunsa' mango [6].

The effect of calcium hydroxide or lime in reducing weight loss and anthracnose incidence might be attributed to the effect of calcium in maintaining the membrane's integrity and stability [24]. The effect of calcium in cell wall strengthening was also observed in 'Samar Bahisht Chaunsa' mango, where fruit retained acceptable firmness [25]. The reduction of decay in the calcium-treated apple was associated with the calcium effect on maintaining cell wall structure [26]. On the other hand, alum at $1 \%$ reduced staining, which was similar to water. A study on bananas has shown the coagulating property of alum on 
sap [27]. The sulfur content of alum inhibits the enzyme polyphenol oxidase (PPO), which is primarily responsible for browning caused by sap [6,26].

In the packinghouse, the fruit is usually washed with water upon arrival to remove the stain caused by sap [28]. In 'Karuthakolumban' and 'Willard' mangoes, the chemical treatments or careful removal of stalk and washing with water after sap collection showed the importance of the control of sap burn injury [5]. In the present study, water alone showed a similar effect with the other desapping agents that had water as a solvent. Water as a universal solvent has a high dipole moment and the ability to donate and accept protons, making it an excellent solvent for electrolytes and polar compounds such as salts, acids, sugars, alcohols, carbonyl compounds [29]. The mango sap is an acidic substance with two phases with different components, the lower aqueous and upper non-aqueous phases [4,18]. The lower aqueous phase contains proteins, proteases, polyphenols, and peroxidases, while the non-aqueous phase contains terpenelike compounds, alk(en)ylresorcinols.

It seemed that control fruit showed lime and water exhibited a lower degree of anthracnose and longer shelf life. In control fruit, the alkenyl- and alkylresorcinols from the sap left in the fruit stem and peel contain antifungal compounds, which are higher in anthracnose-resistant varieties of mango [8,22]. Likewise, chitinase activity in sap has the property to digest certain pathogenic fungi' conidia [21]. This may have contributed to the comparable effect of control to lime and water. However, control fruit also showed a high degree of sap injury that would downgrade the overall quality of fruit and a cause of fruit rejection, especially in the export facility.

It has been reported that careful handling and improved postharvest handling of mango, such as the retention of 4 to 6 -inch long pedicels, desapping in $0.5 \%$ lime solution $\left[\mathrm{Ca}(\mathrm{OH})_{2} ; 2-3\right.$ min dip] followed by washing with water, have potential in maintaining the good quality of fruit [30]. A 20 min ultrasonic washing using a combination of desapping materials such as alum and detergent removed aged sap stain and reduced sap injury in 'Carabao' mangoes [9]. In this study, harvesting later in the day, cutting at the abscission zone, and washing mangoes with water can reduce sap damage.

\section{Conclusions}

The effects of harvest time, delay in destemming and desapping treatment on the sap volume, and visual quality of 'Carabao' mango fruit were evaluated. Fruit harvested in the early morning, wherein the relative humidity was higher, tended to produce higher sap volume. This shows that the surrounding condition RH may influence the production of sap. However, the temperature did not appear to indicate a trend with sap production. It may be advantageous to harvest 'Çarabao' mango fruit between 1:00 to 5:00 PM when RH was lower as fruit produced lower sap volume. Though sap injury did not vary throughout the day, the visual quality of mango harvested in the afternoon seemed to be better than fruit harvested in the morning. Production of sap was not affected by the delayed cutting of the pedicel and the location of the cut. However, a 44 and $34 \%$ reduction in sap volume were recorded when the fruit were destemmed in the base and abscission zone, respectively. Though sap injury was not affected by the location of the cut, cutting off the pedicel at the abscission zone rather than at the pedicel base tended to result in slightly better visual quality and delayed ripening of fruit. This showed that cutting pedicel at the abscission zone upon harvest can affect the visual quality and ripening of fruit during storage. All desapping treatments, $1 \%$ alum, $1.0 \%$ detergent, $0.5 \%$ lime, and water, especially the latter, resulted in lower sap injury and better visual quality of the fruit than the control lot. Except for detergent and alum, the rest of the desapping treatments and untreated fruit showed a lower degree of anthracnose. Stem-end rot did vary among desapping agents. Water alone was able to reduce sap damage. Harvesting later in the day, cutting at the abscission zone, and washing mangoes with water can reduce sap damage in 'Carabao' mango.

\section{Acknowledgement}

The authors would like to thank the Australian Centre for Agricultural Research (ACIAR) for the research funds. 


\section{References}

[1] JH Crane, S Salazar-Garcia, AC Lin, ACDQ Pinto and ZH Shu. Crop Production: Mango. In: RE Litz (Ed.). The mango: Botany, production and uses. $2^{\text {nd }}$ ed. CAB International, Cambridge, MA, 2009, p. 432-83.

[2] EB Esguerra and OK Bautista. Quality and safety in agri-food chains in the Philippines: The case of mango. Acta Hortic. 2013; 989, 239-43.

[3] CM Protacio. Towards a Good Agricultural Practice (GAP)-compliant mango production system in the Philippines. Acta Hortic. 2013; 992, 69-73.

[4] KS John, SG Bhat and UJS Rao. Involvement of peroxidase and polyphenol oxidase in mango sap injury. J. Food Biochem. 2002; 26, 403-14.

[5] N Krishnapillai and RSW Wijeratnam. Sap burn injury management of mangoes (Mangifera indica L.) in Sri Lanka. Pak. J. Bot. 2016; 48, 2147-52.

[6] M Amin, AU Malik, MS Mazhar, I Din, MS Khalid and S Ahmad. Mango fruit desapping in relation to time of harvesting. Pak. J. Bot. 2008; 40, 1587-93.

[7] M Maqbool, AU Malik and A Jabbar. Sap dynamics and its management in commercial mango cultivars of Pakistan. Pak. J. Bot. 2007; 39: 1565-74.

[8] K Barman, A Ram, RK Pal, SK Jha and S Sharma. Influence of different desapping agents on the incidence of sapburn, ripening behaviour and quality of mango. J. Food Sci. Tech. 2015; 52, 161-70.

[9] EZ Davalos and DT Danilo. Effects of age of latex and time of delatexing using ultrasonic washing of alum on the quality of Carabao mango (Mangifera indica L.). PhilMech. 2013; 20, 19.

[10] GMB Madrigal. 2005, Chemical and physical methods of removing latex stains in mango (Mangifera indica Linn. cv. Carabao) fruits. Bachelor Thesis. University of the Philippines Los Baños, Laguna, Philippines.

[11] Philippine Council for Agriculture, Aquatic and Natural Resources Research and Development. Mango Production Manual. Philippine Council for Agriculture, Aquatic and Natural Resources Research and Development, Los Baños, 2006.

[12] JH Ekman, A Goldwater, EV Bayogan, LB Secretaria, AT Lacap, CS Lubaton, VG Monterde, MM Benitez, AD Valida, EE Sudaria, AS Salabao, FC Rivera, MM Sudaria, EP Hinayon, DC Joyce, ST Anh, K Mott, M Perkins and B Bhandari. Improved postharvest management of a fruit and vegetables in the Southern Philippines and Australia. Final Report, ACIAR HORT 2012/098. Australian Centre for International Agricultural Research, Canberra, 2019.

[13] DG Alvindia and MA Acda. Revisiting the efficacy of hot water treatment in managing anthracnose and stem-end rot diseases of mango cv. 'Carabao'. Crop Prot. 2015; 67, 96-101.

[14] G Montanaro, B Dichio and C Xiloyannis. Fruit transpiration: Mechanisms and significance for fruit nutrition and growth. In: G Montanaro and B Dichio (Eds.). Advances in selected plant physiology aspects. Intech Open, 2012, p. 233-50.

[15] H Higuchi and T Sakuratani. Water dynamics in mango (Mangifera indica L.) fruit during the young and mature fruit seasons as measured by the stem heat balance method. J. Japan. Soc. Hort. Sci. 2015; 75, 11-9.

[16] E Pesis, D Aharoni, Z Aharon, R Ben-Arie, N Aharoni and Y Fuchs. Modified atmosphere and modified humidity packaging alleviates chilling injury symptoms in mango fruit. Postharvest Biol. Tech. 2000; 19, 93-101.

[17] M Maqbool and AU Malik. Anti-sap chemicals reduce sapburn injury and improve fruit quality in commercial mango cultivars of Pakistan. Int. J. Agr. Biol. 2008; 10, 1-8.

[18] BR Loveys, SP Robinson, JJ Brophy, J and EK Chacko. Mango sapburn: Components of fruit sap and their role in causing skin damage. Aust. J. Plant Physiol. 1992; 19, 449-57.

[19] TK Lim and W Kuppelweiser. Mango sapburn amelioration in the Northern Territory. Acta Hortic. 1993; 341, 518-27.

[20] TJ O'Hare and A Prasad. The alleviation of sap-induced mango skin injury by calcium hydroxide. Acta Hortic. 1992; 321, 372-81. 
http://wjst.wu.ac.th

[21] KOLC Karunanayake, GD Sinniah, NKB Adikaram, CL Abayasekara and DS Wijayasekara. Retention of sap at harvest, enhanced mango (Mangifera indica L.) fruit resistance and reduced anthracnose and stem-end rot. Australas. Plant Pathol. 2014; 43, 113-9.

[22] O Galsurker, S Diskin, D Maurer, O Feygenberg and N Alkan. Review: Fruit stem-end rot. Horticulturae 2018; 4, 1-16.

[23] K Saby John, SG Bhat and UJ Prasada Rao. Biochemical characterization of sap (latex) of a few Indian mango varieties. Phytochemistry 2003; 62, 13-9.

[24] EA Kirkby and DJ Pilbeam. Calcium as a plant nutrient. Plant Cell Environ. 1984; 7, 397-405.

[25] A Jabbar, AU Malik, A Maqbool, A Amin, M Saeed and R Hameed. Anti-sap chemicals and hot water quarantine treatment effects on storage life and fruit quality of mango cv. Samar Bahist Chaunsa. Pak. J. Bot. 2012; 44, 757-64.

[26] RB Tobias, WS Conway and CE Sams. Cell wall composition of calcium-treated apples inoculated with Botrytis cineraria. Phytochemistry 1993; 32, 35-9.

[27] GM Mortuza and LL Hag. Control of banana fruit rots by alum. Musarama 1996; 32, 70-1.

[28] JDLC Medina and HS García. Mango: Post-harvest operations, Available at: http://www.fao.org/fileadmin/user_upload/inpho/docs/Post_Harvest_Compendium_-_Mango.pdf, accessed April 2020.

[29] RK Mohammad. Use of water properties in food technology: A global view. Int. J. Food Prop. 2014; 17, 1034-54.

[30] MS Mazhar, M Amin, AU Malik, J Campbell and P Johnson. Improved harvest and desapping practices affect mango fruit quality along the supply chains. Int. J. Agr. Biol. 2011; 13, 776-80. 